\title{
DETECTION OF Leishmania (Viannia) IN Nyssomyia neivai AND Nyssomyia whitmani BY MULTIPLEX POLYMERASE CHAIN REACTION, IN SOUTHERN BRAZIL
}

Herintha Coeto NEITZKE-ABREU(1), Kárin Rosi REINHOLD-CASTRO(1), Mateus Sabaini VENAZZI(2), Regiane Bertin de Lima SCODRO(3), Alessandra de Cassia DIAS(1), Thaís Gomes Verzignassi SILVEIRA(1,3), Ueslei TEODORO(1) \& Maria Valdrinez Campana LONARDONI(1,3)

\begin{abstract}
SUMMARY
Sandflies transmit pathogens of leishmaniasis. The natural infection of sandflies by Leishmania (Viannia) was assessed in municipalities, in the state of Paraná, in Southern Brazil. Sandflies were collected with Falcão and Shannon traps. After dissection in search of flagellates in digestive tubes and identification of the species, female sandflies were submitted to the Multiplex Polymerase Chain Reaction (multiplex PCR) for detection of the fragment of the kDNA of Leishmania (Viannia) and the fragment from the IVS6 cacophony gene region of the phlebotomine insects. The analysis was performed in pools containing seven to 12 guts from females of the same species. A total of 510 female sandflies were analyzed, including nine Migonemyia migonei, 17 Pintomyia fischeri, 216 Nyssomyia neivai, and 268 Nyssomyia whitmani. Although none of the females was found naturally infected by flagellates through dissection, the fragment of DNA from Leishmania (Viannia) was shown by multiplex PCR in one sample of Ny. neivai (0.46\%) and three samples of $N y$. whitmani (1.12\%). It was concluded that $N y$. neivai and $N y$. whitmani are susceptible to Leishmania infection, and that multiplex PCR can be used in epidemiological studies to detect the natural infection of the sandfly vector, because of its sensitivity, specificity and feasibility.
\end{abstract}

KEYWORDS: Cutaneous leishmaniasis; Sandfly; PCR; Leishmania; Nyssomyia whitmani; Nyssomyia neivai.

\section{INTRODUCTION}

Knowledge of the fauna composition, behavior, rates of natural infection of the sandfly, Leishmania species identification, and environmental characteristics of endemic areas are essential for the public-health services responsible for protecting populations that live in areas in which leishmaniasis is endemic. Leishmaniasis has worldwide propagation. In Brazil, cutaneous leishmaniasis (CL) has been reported in all states ${ }^{3}$

Cases of CL have increased significantly since the 1980s, and are appearing over wider areas in the State of Paraná, in the South of Brazil $^{28,29}$. This disease has been recorded in occupied areas for more than a century, even in urban areas, contrary to expectations that human pressure would eliminate natural foci and reduce the incidence of this endemic disease ${ }^{16,33,46}$. The organization of rural areas in the Brazilian colonial period created environmental conditions that clearly favor CL transmission $^{28}$.

There are several reports of Leishmania detection in sandflies in endemic CL areas in Brazil and in the world ${ }^{1,32,41}$. However, considering the wide geographical distribution of this dermatosis in the Americas ${ }^{47}$, knowledge of the natural infection rate of sandflies is still insufficient to estimate the risk of Leishmania infection in many endemic areas.

Given the occurrence of autochthonous CL cases in several municipalities, in the state of Paraná, natural infection rates of sandflies by Leishmania (Viannia) were investigated, in order to identify the species of Leishmania present in locations where cases of this disease had been reported.

\section{MATERIAL AND METHODS}

Sandfly collection: Sandflies were collected in the localities of Recanto Marista, Água Azul Farm and Flor de Maio Grange, in the municipalities of Doutor Camargo, Fênix and Mandaguari, respectively, in the state of Paraná, where CL cases had been reported. Sandflies were collected from January through September 2006, from 6 p.m. to 6 a.m., with Falcão light traps and a Shannon trap, installed in woods, domiciles, peridomicile and domestic-animal shelters (cattle shelter and pigsty $)^{30}$. The collected insects were kept alive for further dissection and observation of the natural infection by flagellates.

Dissection and identification of sandflies: The dissection was carried

(1) Programa de Pós Graduação em Ciências da Saúde, Universidade Estadual de Maringá, Maringá, Paraná, Brazil.

(2) Departamento de Medicina, Universidade Estadual de Maringá, Maringá, Paraná, Brazil.

(3) Departamento de Análises Clínicas e Biomedicina, Universidade Estadual de Maringá, Maringá, Paraná, Brasil.

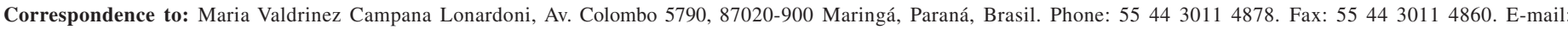
mvclonardoni@gmail.com 


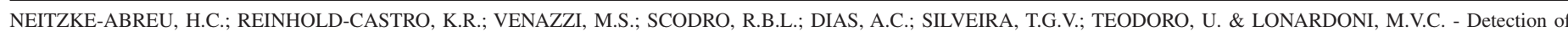
Leishmania (Viannia) in Nyssomyia neivai and Nyssomyia whitmani by Multiplex Polymerase Chain Reaction, in Southern Brazil. Rev. Inst. Med. Trop. Sao Paulo, 56(5): 391-5, 2014.

out under a stereoscope; the legs and wings were removed and the dissection was carried out by making two incisions in the distal portion of the abdomen and, with zigzag movements, the digestive tubes were removed and examined under an optical microscope $(400 \mathrm{x})$ in the search for flagellates and the identification of the species of the sandfly ${ }^{30}$. The nomenclature of the species follows GALATI ${ }^{12}$.

After dissection and identification ${ }^{30}$ of species, digestive tubes were stored at $-18{ }^{\circ} \mathrm{C}$ in tubes containing $150 \mu \mathrm{L}$ STE buffer $(0.1 \mathrm{M} \mathrm{NaCl}, 10$ mM Tris-base; $\mathrm{Na}_{2}$ EDTA-2 $\mathrm{H}_{2} \mathrm{O} 1 \mathrm{mM}$, pH 8.0), each containing seven to 12 guts from females of the same species.

Extraction of DNA: The samples were macerated, and DNA was extracted with a solution of guanidine isothiocyanate and phenol, and hydrated in $20 \mu \mathrm{L}$ of ultra-pure $\mathrm{H}_{2} \mathrm{O}^{31}$. For each group of 22 samples submitted for DNA extraction, one negative control (male sandflies) and one positive control [male sandflies plus $10^{4} \mathrm{~L}$. (V.) braziliensis promastigotes] were used.

Multiplex PCR: Two pairs of primers were used: MP3H (5'-GAA CGG GGT TTC TGT ATG C-3') and MP1L (5'-TAC TCC CCG ACA TGC CTC TG-3 $\left.{ }^{\prime}\right)^{18}$ to amplify a fragment of 70 -bp from the mini circle region of the kinetoplast (kDNA) of the Leishmania (Viannia), and 5Llcac (5'-TGG CCG AAC ATA ATG TTA G-3') and 3Llcac (5'-CCA CGA ACA AGT TCA ACA TC-3' $)^{17}$ to amplify a fragment of 220 -bp from the IVS6 cacophony gene region of the phlebotomine insects.

The PCR reaction mixture (final volume $25 \mu \mathrm{L}$ ) was composed of $0.5 \mu \mathrm{M}$ of each of the primers (Invitrogen Life Technologies, São Paulo, Brazil), 0.2 mM dNTP (Invitrogen, Carlsbad, CA, USA), 1U Platinum Taq DNA Polymerase, (Invitrogen, Carlsbad, CA, USA), $1.5 \mathrm{mM} \mathrm{MgCl}$, $1 \mathrm{X}$ enzyme buffer, and $2 \mu \mathrm{L}$ DNA template. The amplification was carried out in a PC Thermocycler (Biometra, Germany) at $94{ }^{\circ} \mathrm{C}$ for seven min to activate the enzyme, followed by 30 cycles, each divided into three stages, of denaturation $\left(1.5 \mathrm{~min}\right.$ at $\left.95^{\circ} \mathrm{C}\right)$, annealing $\left(1.5 \mathrm{~min}\right.$ at $\left.57^{\circ} \mathrm{C}\right)$, and polymerization (two min at $72{ }^{\circ} \mathrm{C}$ ). After this, the extension was continued for a further $10 \mathrm{~min}$ at $72{ }^{\circ} \mathrm{C}$, and the tubes were then kept at $4{ }^{\circ} \mathrm{C}$ until analysis ${ }^{31}$. The amplification products were submitted to electrophoresis in $2 \%$ of agarose gel (Invitrogen, Paisley, Scotland, UK) stained with $0.1 \mu \mathrm{g} / \mathrm{mL}$ ethidium bromide, at $10-15 \mathrm{~V} / \mathrm{cm}$. The presence of bands was observed in a transilluminator (Macro Vue ${ }^{\mathrm{TM}} \mathrm{UV}-20$, Hoefer). For every five samples, one positive control [reaction mixture plus $L$. (V.) braziliensis DNA] and one negative control (reaction mixture plus water) were added.

\section{RESULTS}

In total, 510 (52 pools) female sandflies were analyzed by dissection and multiplex PCR, including nine Migonemyia migonei (one pool), 17 Pintomyia fischeri (two pools), 216 Nyssomyia neivai (22 pools), and 268 Nyssomyia whitmani (27 pools) (Table 1). A total of 244 female sandflies were collected at Recanto Marista, 107 at Água Azul Farm, and 159 at Flor de Maio Grange (Table 1).

All 52 sandfly pools contained the 220-bp fragment from the IVS6 cacophony gene region of the sandflies, and four pools $(7.7 \%)$ showed the 70-bp fragment from the mini circle kDNA of Leishmania (Viannia) (Fig. 1). The minimal infection rate of $N y$. neivai was $0.46 \%(1 / 216)$, and of $N y$. whitmani was $1.12 \%$ (3/268). At Recanto Marista one Ny. neivai pool with Leishmania infection was detected on the porch of a domicile; at Água Azul Farm, one Ny. whitmani pool was detected in the peridomicile (near the woods ); and at Flor de Maio Grange, two Ny. whitmani pools were detected, one on the porch of a domicile and another from a domestic-animal shelter. The minimal infection rate of Recanto Marista was $0.41 \%$ (1/244), of Flor de Maio Grange was $1.26 \%$ (2/159), and at Água Azul Farm was $0.93 \%$ (1/107).

\section{DISCUSSION}

Mi. migonei, Pi. fischeri, Ny. neivai, and Ny. whitmani are frequently found in Brazil $1,2,4,31,34,35,43,46$. Both species detected with Leishmania infection are widely propagated in Brazil $1^{4,5,6,9,20,21}$ and in the state of

Table 1

Sandflies collected in Recanto Marista, Água Azul Farm, and Flor de Maio Grange, in Southern Brazil, from January to September, 2006

\begin{tabular}{|c|c|c|c|c|c|}
\hline \multicolumn{2}{|c|}{ Specimens/Localities (Municipalities) } & \multirow{2}{*}{$\begin{array}{c}\begin{array}{c}\text { Recanto Marista } \\
\text { (Doutor Camargo) }\end{array} \\
9\end{array}$} & \multirow{2}{*}{$\begin{array}{c}\text { Água Azul Farm } \\
\text { (Fênix) } \\
0\end{array}$} & \multirow{2}{*}{$\begin{array}{c}\text { Flor de Maio Grange } \\
\text { (Mandaguari) }\end{array}$} & \multirow{2}{*}{$\begin{array}{c}\text { Total } \\
9\end{array}$} \\
\hline & $\mathrm{N}^{\mathrm{a}}$ & & & & \\
\hline ingonemyia migonet & Positive pools / Pools ${ }^{\mathrm{b}}$ & $0 / 1$ & $0 / 0$ & $0 / 0$ & $0 / 1$ \\
\hline \multirow{2}{*}{ Nyssomyia whitmani } & $\mathrm{N}^{\mathrm{a}}$ & 19 & 97 & 152 & 268 \\
\hline & Positive pools / Pools ${ }^{b}$ & $0 / 2$ & $1 / 10$ & $2 / 15$ & $3 / 27$ \\
\hline \multirow{2}{*}{ Nyssomyia neivai } & $\mathrm{N}^{\mathrm{a}}$ & 216 & 0 & 0 & 216 \\
\hline & Positive pools / Pools ${ }^{\mathrm{b}}$ & $1 / 22$ & $0 / 0$ & $0 / 0$ & $1 / 22$ \\
\hline \multirow{2}{*}{ Pintomyia fischeri } & $\mathrm{N}^{\mathrm{a}}$ & 0 & 10 & 7 & 17 \\
\hline & Positive pools / Pools ${ }^{\mathrm{b}}$ & $0 / 0$ & $0 / 1$ & $0 / 1$ & $0 / 2$ \\
\hline \multirow{2}{*}{ Total } & $\mathrm{N}^{\mathrm{a}}$ & 244 & 107 & 159 & 510 \\
\hline & Positive pools / Pools ${ }^{\mathrm{b}}$ & $1 / 25$ & $1 / 11$ & $2 / 16$ & $4 / 52$ \\
\hline
\end{tabular}

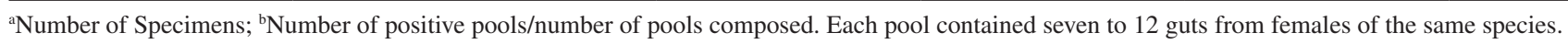




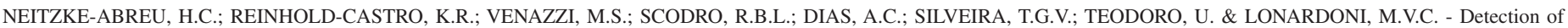
Leishmania (Viannia) in Nyssomyia neivai and Nyssomyia whitmani by Multiplex Polymerase Chain Reaction, in Southern Brazil. Rev. Inst. Med. Trop. Sao Paulo, 56(5): 391-5, 2014.

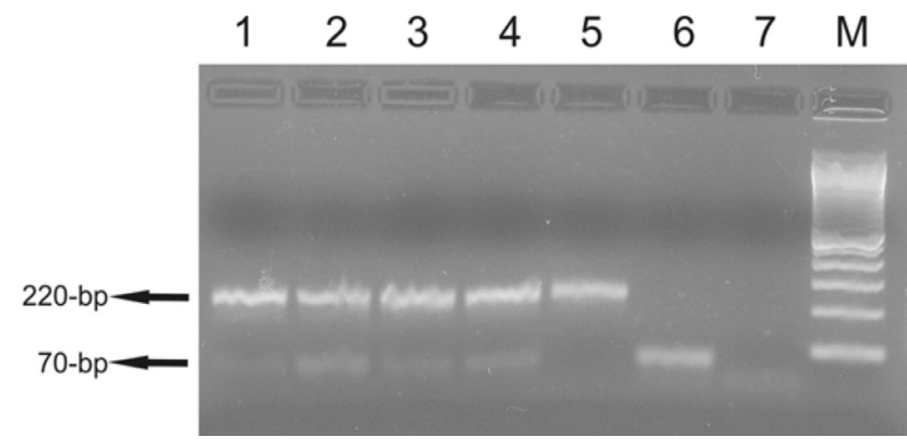

Fig 1 - Multiplex PCR in 2\% of agarose gel showing fragments of 70-bp and 220-bp. The fragment of 70-bp of the kDNA mini circle region of subgenus Leishmania (Viannia) were amplified with MP3H and MP1L primers. The fragment of 220-bp of the IVS6 cacophony gene region of the phlebotomine insects were amplified with 5Llcac and 3Llcac primers. Lane 1, Ny. whitmani DNA sample collected in Fênix; lanes 2, 3 and 5, Ny. whitmani DNA samples collected in Mandaguari; lane 4, Ny. neivai DNA sample collected in Doutor Camargo; lane 6, positive control [DNA from $L$. (V.) braziliensis promastigotes]; lane 7, negative control (all reagents without DNA). M, 100-bp molecular marker (Invitrogen Life Technologies, São Paulo, Brazil).

Paraná, where either Ny. whitmani or Ny. neivai predominate, depending on environmental characteristics ${ }^{26,42,43,46}$.

Although no flagellates were detected in the dissected sandfly digestive tubes, DNA from Leishmania (Viannia) was found in $0.78 \%$ (4/510), indicating that at least one infected sandfly was present in each positive pool. The infected specimens were collected at sites near a riparian forest, which is inhabited by small wild mammals (e.g. rodents, armadillo) that are possible natural reservoirs of Leishmania. These locations show favorable environment for the formation of sandflybreeding sites. Furthermore, the domestic animals are highly attractive blood sources for female sandflies ${ }^{37,44,45}$. Natural infection by Leishmania has been recorded in Pi. fischeri ${ }^{23,36,38}$, Mi. migonei $^{2,7,34}, N y$. neivai ${ }^{8,22,31,41,47}$, and $N y$. whitmani $i^{1,411,19}$, by dissection or PCR, in several localities in many of the Brazilian states.

Natural infection rates of sandflies by Leishmania vary widely: $15.68 \%$ in Venezuela by $\mathrm{PCR}^{13}, 0.83 \%$ and $7.14 \%{ }^{4}$, and $18.2 \%{ }^{23}$, in Brazil, by $\mathrm{PCR}^{4}$, and $1.4 \%$ and $2.6 \%$, in Peru, by dissection ${ }^{15}$. Studies on natural infection rates have revealed that PCR is more sensitive and specific than dissection showing the presence of Leishmania in sandflies ${ }^{10,27,39,40}$. This method has often been used in areas where sandfly infection rates are low ${ }^{27,31}$, due to its sensitivity (it is able to detect the presence of a single parasite), specificity (independently of the number, location and stage of flagellates in the digestive tubes of the vector $)^{25,27,34}$, rapidity, and ease of performance enabling it to be used in leishmaniasis epidemiological surveillance ${ }^{24}$. The dissection of sandflies for the detection of flagellates in the digestive tubes needs confirmation by Leishmania in vitro, cultivation or inoculation in laboratory animals ${ }^{27}$ while molecular methods allow the identification of Leishmania species, isolated in cultures from patients or reservoirs, as well from sandflies ${ }^{25,27}$.

Several primers have been used ${ }^{14,27,34}$, however, the primers used in this study have been tested successfully in diagnosis and detection of naturally infected sandflies, besides having good sensitivity $[8 \mathrm{fg} / \mu \mathrm{L}$ of Leishmania (Viannia) $]^{31}$.
The advantage of employing the multiplex PCR technique is that, in addition to the primers for detection of Leishmania (Viannia), the pair of primers used for internal control can assess the presence of probable interference from digestive contents of insects, which can inhibit the detection of Leishmania ${ }^{31,34}$.

The results show the susceptibility of sandflies to Leishmania strains. The minimum infection rates in Ny. neivai $(0.46 \%, 1 / 216)$ and Ny. whitmani $(1.12 \%, 3 / 268)$ are low, and might explain the low CL endemicity in the municipalities in question. Multiplex PCR, because of its sensitivity, specificity and feasibility, can be used in epidemiological studies to detect the natural infection of the sandfly vector.

\section{RESUMO}

\section{Detecção de Leishmania (Viannia) em Nyssomyia neivai e Nyssomyia whitmani por Multiplex Reação em Cadeia da Polimerase, no sul do Brasil}

Flebotomíneos transmitem os patógenos das leishmanioses. Foi avaliada a infecção natural de flebotomíneos por Leishmania (Viannia) em municípios do Estado do Paraná, sul do Brasil. Os flebotomíneos foram coletados com armadilhas de Falcão e Shannon. Após dissecação para pesquisa de flagelados no tubo digestório e identificação das espécies, as fêmeas de flebotomíneos foram submetidas a Multiplex Reação em Cadeia da Polimerase (multiplex PCR) para a detecção do fragmento do kDNA de Leishmania (Viannia) e do fragmento do gene IVS6 da cacofonia de flebotomíneos. A análise foi realizada em pools contendo sete a 12 tubos digestórios de fêmeas da mesma espécie. Um total de 510 fêmeas foram analisadas, incluindo nove Migonemyia migonei, 17 Pintomyia fischeri, 216 Nyssomyia neivai e 268 Nyssomyia whitmani. Embora nenhuma fêmea tenha sido encontrada naturalmente infectada com flagelados pela dissecação, o fragmento de DNA de Leishmania (Viannia) foi mostrado por multiplex PCR em uma amostra de Ny. neivai $(0,46 \%)$ e três amostras de $N y$. whitmani $(1,12 \%)$. Conclui-se que $N y$. neivai e $N y$. whitmani são suscetíveis à infecção por Leishmania, e que multiplex PCR, devido à sua sensibilidade, especificidade e viabilidade, pode ser utilizada em estudos epidemiológicos para a detecção da infecção natural do inseto vetor.

\section{ACKNOWLEDGEMENTS}

The authors would like to thank Colégio Marista, Água Azul Farm, and Flor de Maio Grange, for the permission granted to conduct the assessments, and for logistical support. Conselho Nacional de Desenvolvimento Científico e Tecnológico (CNPq Process 410550/20060), Coordenação de Aperfeiçoamento de Pessoal de Nível Superior (CAPES), and Fundação Araucária for their financial support.

\section{REFERENCES}

1. Azevedo ACR, Rangel EF, Costa EM, David J, Vasconcelos AW, Lopes UG. Natural infection of Lutzomyia (Nyssomyia) whitmani (Antunes \& Coutinho, 1939) by Leishmania of the braziliensis complex in Baturité, Ceará State, northeast Brazil. Mem Inst Oswaldo Cruz. 1990;85:251.

2. Azevedo ACR, Rangel EF, Queiroz RG. Lutzomyia migonei (França, 1920) naturally infected with peripylarian flagellates in Baturité, a focus of cutanous leishmaniasis in Ceará State, Brazil. Mem Inst Oswaldo Cruz. 1990;85:479. 
NEITZKE-ABREU, H.C.; REINHOLD-CASTRO, K.R.; VENAZZI, M.S.; SCODRO, R.B.L.; DIAS, A.C.; SILVEIRA, T.G.V.; TEODORO, U. \& LONARDONI, M.V.C. - Detection of Leishmania (Viannia) in Nyssomyia neivai and Nyssomyia whitmani by Multiplex Polymerase Chain Reaction, in Southern Brazil. Rev. Inst. Med. Trop. Sao Paulo, 56(5): 391-5, 2014.

3. Brasil, Ministério da Saúde. Manual de vigilância da leishmaniose tegumentar americana. Available from: http://goo.gl/mPcbz.

4. Carvalho GM, Andrade-Filho JD, Falcão AL, Rocha-Lima AC, Gontijo CM. Naturally infected Lutzomyia sand flies in a Leishmania-endemic area of Brazil. Vector Borne Zoonotic Dis. 2008;8:407-14.

5. Carvalho MSL, Bredt A, Meneghin ERS, Oliveira C. Flebotomíneos (Diptera: Psychodidae) em áreas de ocorrência de leishmaniose tegumentar americana no Distrito Federal, Brasil, 2006 a 2008. Epidemiol Serv Saúde. 2010;19:227-37.

6. Carvalho SMS, Santos PRB, Lanza H, Brandão-Filho SP. Diversidade de flebotomíneos no município de Ilhéus, Bahia. Epidemiol Serv Saúde. 2010;19:239-44.

7. Carvalho MR, Valença HF, Silva FJ, Pita-Pereira D, Araújo-Pereira T, Britto C, et al. Natural Leishmania infantum infection in Migonemyia migonei (França, 1920) (Diptera: Psychodidae: Phlebotominae) the putative vector of visceral leishmaniasis in Pernambuco State, Brazil. Acta Trop. 2010;116:108-10.

8. Córdoba-Lanús E, De Grosso ML, Piñero JE, Valladares B, Salomón OD. Natural infection of Lutzomyia neivai with Leishmania spp. in northwestern Argentina. Acta Trop. 2006;98:1-5.

9. Costa SM, Cechinel M, Bandeira V, Zannuncio JC, Lainson R, Rangel EF. Lutzomyia (Nyssomyia) whitmani s.l. (Antunes \& Coutinho, 1939) (Diptera: Psychodidae: Phlebotominae): geographical distribution and the epidemiology of American cutaneous leishmaniasis in Brazil: mini-review. Mem Inst Oswaldo Cruz. 2007; 102:149-53.

10. Dinesh DS, Kar SK, Kishore K, Palit A, Verma N, Gupta AK, et al. Screening sandflies for natural infection with Leishmania donovani, using a non-radioactive probe based on the total DNA of the parasite. Ann Trop Med Parasitol. 2000;94:447-51.

11. Galati EAB, Nunes VLB, Dorval MEC, Oshiro ET, Cristaldo G, Espíndola MA, et al. Estudo dos flebotomíneos (Diptera, Pychodidae) em área de leishmaniose tegumentar, no Estado de Mato Grosso do Sul, Brasil. Rev Saúde Pública. 1996;30:115-28.

12. Galati EAB. Morfologia e taxonomia. In: Rangel EF, Lainson R, editores. Flebotomíneos do Brasil. Rio de Janeiro: Fiocruz; 2003. p. 23-51.

13. Jorquera A, González R, Marchán-Marcano E, Oviedo M, Matos M. Multiplex-PCR for detection of natural Leishmania infection in Lutzomyia spp. captured in an endemic region for cutaneous leishmaniasis in state of Sucre, Venezuela. Mem Inst Oswaldo Cruz. 2005;100:45-8.

14. Kato H, Uezato H, Katakura K, Calvopiña M, Marco JD, Barroso PA, et al. Detection and identification of Leishmania species within naturally infected sand flies in the Andean areas of Ecuador by a polymerase chain reaction. Am J Trop Med Hyg. 2005;72:87-93

15. Kato H, Gomez EA, Cáceres AG, Vargas F, Mimori T, Yamamoto K, et al. Natural infections of man-biting sand flies by Leishmania and Trypanosoma species in the northern Peruvian Andes. Vector Borne Zoonotic Dis. 2011;11:515-21.

16. Lima AP, Minelli L, Teodoro U, Comunello E. Tegumentary leishmaniasis distribution by satellite remote sensing imagery, in Paraná State, Brazil. An Bras Dermatol. $2002 ; 77: 681-92$.

17. Lins RM, Oliveira SG, Souza NA, Queiroz RG, Justiniano SC, Ward RD, et al. Molecular evolution of the cacophony IVS6 region in sandflies. Insect Mol Biol. 2002;11:117-22.

18. Lopez M, Inga R, Cangalaya M, Echevarria J, Llanos-Cuentas A, Orrego C, et al. Diagnosis of Leishmania using the polymerase chain reaction: a simplified procedure for field work. Am J Trop Med Hyg. 1993;49:348-56.

19. Luz E, Membrive N, Castro EA, Dereure J, Pratlong F, Dedet JA, et al. Lutzomyia whitmani (Diptera: Psychodidae) as vector of Leishmania (V.) braziliensis in Paraná State, southern Brazil. Ann Trop Med Parasitol. 2000;94:623-31.
20. Marcondes CB, Lozovei AL, Vilela JH. Distribuição geográfica de flebotomíneos do complexo Lutzomyia intermedia (Lutz \& Neiva, 1912) (Diptera, Psychodidae). Rev Soc Bras Med Trop. 1998;31:51-8.

21. Marcondes CB, Conceição MBE, Portes MGT, Simão BP. Phlebotomine sandflies in a focus of dermal leishmaniasis in the eastern region of the Brazilian state of Santa Catarina - preliminary results (Diptera: Psychodidae). Rev Soc Bras Med Trop. 2005;38:353-5.

22. Marcondes CB, Bittencourt IA, Stoco PH, Eger I, Grisard EC, Steindel M. Natura infection of Nyssomyia neivai (Pinto, 1926) (Diptera: Psychodidae, Phlebotominae) by Leishmania (Viannia) spp. in Brazil. Trans R Soc Trop Med Hyg. 2009;103:1093-7.

23. Margonari C, Soares RP, Andrade-Filho JD, Xavier DC, Saraiva L, Fonseca AL, et al. Phlebotomine sand flies (Diptera: Psychodidae) and Leishmania infection in Gafanhoto Park, Divinópolis, Brazil. J Med Entomol. 2010;47:1212-9.

24. Martín-Sánchez J, Gállego M, Barón S, Castillejo S, Morillas-Marques F. Pool screen PCR for estimating the prevalence of Leishmania infantum infection in sandflies (Diptera: Nematocera, Phlebotomidae). Trans R Soc Trop Med Hyg. 2006;100:527-32.

25. Medeiros ACR, Rodrigues SS, Roselino AMF. Comparison of the specificity of PCR and the histopathological detection of Leishmania for the diagnosis of American cutaneous leishmaniasis. Braz J Med Biol Res. 2002;35:421-4.

26. Membrive NA, Rodrigues G, Membrive U, Monteiro WM, Neitzke HC, Lonardoni MVC et al. Flebotomíneos de municípios do norte do estado do Paraná, sul do Brasil. Entomol Vectores. 2004;11:673-80.

27. Michalsky ÉM, Fortes-Dias CL, Pimenta PFP, Secundino NFC, Dias ES. Assessmen of PCR in the detection of Leishmania spp in experimentally infected individual phlebotomine sandflies (Diptera: Psychodidae: Phlebotominae). Rev Inst Med Trop Sao Paulo. 2002;44:255-9.

28. Monteiro WM, Neitzke HC, Lonardoni MVC, Silveira TGV, Ferreira MEMC, Teodoro U Distribuição geográfica e características epidemiológicas da leishmaniose tegumentar americana em áreas de colonização antiga do Estado do Paraná, Sul do Brasil. Cad Saúde Pública. 2008;24:1291-303

29. Monteiro WM, Neitzke HC, Silveira TGV, Lonardoni MVC, Teodoro U, Ferreira MEMC. Pólos de produção de leishmaniose tegumentar americana no norte do Estado do Paraná, Brasil. Cad Saúde Pública. 2009;25:1083-92.

30. Neitzke HC, Scodro RBL, Reinhold-Castro KR, Dias-Sversutti AC, Silveira TGV, Teodoro U. Pesquisa de infecção natural de flebotomíneos por Leishmania, no Estado do Paraná. Rev Soc Bras Med Trop. 2008;41:17-22.

31. Oliveira DM, Reinhold-Castro KR, Bernal MVZ, Legriffon CMO, Lonardoni MVC, Teodoro U, et al. Natural infection of Nyssomyia neivai by Leishmania (Viannia) spp. in the state of Paraná, southern Brazil, detected by multiplex polymerase chain reaction. Vector Borne Zoonotic Dis. 2011;11:137-43.

32. Parvizi P, Ready PD. Nested PCRs and sequencing of nuclear ITS-rDNA fragments detect three Leishmania species of gerbils in sandflies from Iranian foci of zoonotic cutaneous leishmaniasis. Trop Med Int Health. 2008;13:1159-71.

33. Pessoa SB, Barreto MP. Leishmaniose tegumentar americana. Rio de Janeiro: Imprensa Nacional - São Paulo: Serviço de Parasitologia, Departamento de Medicina, Faculdade de São Paulo; 1948.

34. Pita-Pereira D, Alves CR, Souza MB, Brazil RP, Bertho AL, Figueiredo-Barbosa A, et al. Identification of naturally infected Lutzomyia intermedia and Lutzomyia migonei with Leishmania (Viannia) braziliensis in Rio de Janeiro (Brazil) revealed by a PCR multiplex non-isotopic hybridisation assay. Trans R Soc Trop Med Hyg. 2005;99:90513.

35. Pita-Pereira D, Souza GD, Zwetsch A, Alves CR, Britto C, Rangel EF. First report of Lutzomyia (Nyssomyia) neivai (Diptera: Psychodidae: Phlebotominae) naturally infected by Leishmania (Viannia) braziliensis in a periurban area of south Brazil using a multiplex polymerase chain reaction assay. Am J Trop Med Hyg. 2009;80:593-5. 
NEITZKE-ABREU, H.C.; REINHOLD-CASTRO, K.R.; VENAZZI, M.S.; SCODRO, R.B.L.; DIAS, A.C.; SILVEIRA, T.G.V.; TEODORO, U. \& LONARDONI, M.V.C. - Detection of Leishmania (Viannia) in Nyssomyia neivai and Nyssomyia whitmani by Multiplex Polymerase Chain Reaction, in Southern Brazil. Rev. Inst. Med. Trop. Sao Paulo, 56(5): $391-5,2014$.

36. Pita-Pereira D, Souza GD, Pereira TA, Zwetsch A, Britto C, Rangel EF. Lutzomyia (Pintomyia) fischeri (Diptera: Psychodidae: Phlebotominae), a probable vector of American cutaneous leishmaniasis: detection of natural infection by Leishmania (Viannia) DNA in a specimens from the municipality of Porto Alegre (RS), Brazil, using multiplex PCR assay. Acta Trop. 2011;120:273-5.

37. Reinhold-Castro KR, Scodro RBL, Dias-Sversutti AC, Neitzke HC, Rossi RM, Kuhl JB, et al. Avaliação de medidas de controle de flebotomineos. Rev Soc Bras Med Trop. 2008;41:269-76.

38. Rocha LSO, Santos CB, Falqueto A, Grimaldi Jr G, Cupolillo E. Molecular biological identification of monoxenous trypanosomatids and Leishmania from antropophilic sand flies (Diptera: Psychodidae) in Southeast Brazil. Parasitol Res. 2010;107:465-8.

39. Rodriguez N, Aguilar CM, Barrios MA, Barker DC. Detection of Leishmania braziliensis in naturally infected individual sandflies by the polymerase chain reaction. Trans $\mathrm{R}$ Soc Trop Med Hyg. 1999;93:47-9.

40. Rodriguez N, Lima H, Aguilar CM, Rodriguez A, Barker DC, Convit J. Molecular epidemiology of cutaneous leishmaniasis in Venezuela. Trans R Soc Trop Med Hyg. 2002;96(Suppl 1):105-9.

41. Saraiva L, Carvalho GML, Gontijo CMF, Quaresma PF, Lima ACVMR, Falcão AL, et al Natural infection of Lutzomyia neivai and Lutzomyia sallesi (Diptera: Psychodidae) by Leishmania infantum chagasi in Brazil. J Med Entomol. 2009;46:1159-63.
42. Silva AM, Camargo NJ, Santos DR, Massafera R, Ferreira AC, Postai C, et al. Diversidade, distribuição e abundância de flebotomíneos (Diptera: Psychodidae) no Paraná. Neotrop Entomol. 2008;37:209-25.

43. Teodoro U, Santos DR, Santos AR, Oliveira O, Poiani LP, Silva AM, et al. Preliminary information on sandflies in the north of Paraná State, Brazil. Rev Saúde Publica. 2006;40:327-30

44. Teodoro U, Lonardoni MVC, Silveira TGV, Dias AC, Abbas M, Alberton D, et al. Luz e galinhas como fatores de atração de Nyssomyia whitmani em ambiente rural, Paraná, Brasil. Rev Saúde Publica. 2007;41:383-8

45. Teodoro U, Santos DR, Santos AR, Oliveira O, Poiani LP, Kuhl JB, et al. Avaliação de medidas de controle de flebotomineos no norte do Estado do Paraná, Brasil. Cad Saúde Publica. 2007;23:2597-604.

46. Teodoro U, Santos DR, Silva AM, Massafera R, Imazu LE, Monteiro WM, et al. Fauna de flebotomíneos em municípios do norte pioneiro do estado do Paraná, Brasil. Rev Patol Trop. 2010;39:322-30.

47. World Health Organization, Leishmaniasis. Available from: http://goo.gl/PiM9n.

Received: 23 September 2013

Accepted: 10 March 2014 